\title{
THE COMMON LAW OF DEFAMATION FAILS TO ENTER THE AGE OF THE CHARTER
}

\section{JUNE ROSS ${ }^{\circ}$}

\begin{abstract}
In this article the author criticizes the reluctance of the Courts to extend the influence of the Canadian Charter of Rights and Freedoms to the common law as it applies between private parties.

The author explores the courts' application of the Charter to the common law, tracing the development of the jurisprudence through several cases, and goes on to offer an analysis of the implications of this judicial stance for the protection of freedom of expression in the context of defamation law.

The author argues for $a$ reassessment of the current law of defamation, and contends that the Charter's reach should extend to the common law of defamation.
\end{abstract}

L'auteure critique la réticence des tribunaux à étendre l'influence de la Charte canadienne des droits et libertés à la common law telle qu'elle s'applique aux simples particuliers.

Elle examine la façon dont les tribunaux invoquent la Charte en common law, suit l'évolution de la jurisprudence au moyen de plusieurs causes et analyse ensuite les implications de cette position en ce qui touche la protection de la liberté d'expression dans le contexte du droit de la diffamation.

L'auteure réclame une réévaluation du droit de la diffamation et soutient que la portée de la Charte devrait s'étendre à la common law de la diffamation.

\section{TABLE OF CONTENTS}

\section{THE CHARTER'S APPLICATION TO COMMON LAW .... 118 \\ II. THE CHARTER AND DEVELOPMENT

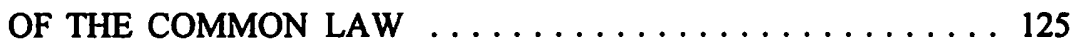

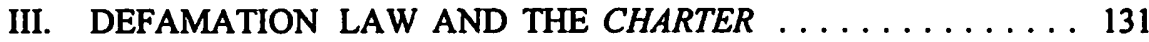

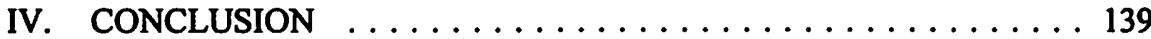

Perhaps more than in any other area of Canadian law, a question about trends and changes in civil liberties lends itself to a quick and easy answer: the Charter. As we all know, the Canadian Charter of Rights and Freedoms ${ }^{1}$ has given the court immense new powers to protect the rights and freedoms of individuals and minorities. One can argue about the wisdom of such a grant of authority to the courts, or about whether it has been under or over utilized, but that it has had a major impact is indisputable. With the Charter as such an overwhelming impetus for development, and a subject of an appropriate scope for treatises, rather than a review, I have decided to focus instead on an exceptional aspect of civil liberties law - the context in which change has not been a significant feature.

One part of Canadian law is in large part untouched by the Charter: the common law. For a number of what I will contend are unsatisfactory reasons the Supreme Court of Canada has refused to extend the reach of the Charter to the common law as it applies between private parties. The Court has indicated that common law should be developed in accordance with Charter values, but, I will further contend, has given

Associate Professor, University of Alberta, Faculty of Law. The author would like to thank David Schneiderman for his review and helpful comments.

1 Canadian Charter of Rights and Freedoms, Part I of the Constitution Act, 1982, being Schedule B to the Canada Act 1982 (U.K.), 1982, c. 11 [hereinafter Charter]. 
insufficient meaning to this concept for the Charter to have any discernable impact. In the result, where rights and freedoms are affected by common law, the judicial deliberations of today may be far too reminiscent of those of seventy-five years ago.

I will address, firstly, the jurisprudence relating to the application of the Charter to common law, commencing with the well-known case of R.W.D.S.U. v. Dolphin Delivery $L_{t d}{ }^{2}$ and leading up to the relatively recent decisions in Dagenais v. Canadian Broadcasting Corp. ${ }^{3}$ and Hill v. Church of Scientology of Toronto. ${ }^{4}$ Secondly, I will consider the implications that this has had for the protection of freedom of expression in the context of defamation law, one area in which conflicts between the common law and the Charter have frequently been alleged.

\section{THE CHARTER'S APPLICATION TO COMMON LAW}

The Supreme Court of Canada first addressed the Charter's application to the common law in Dolphin Delivery. ${ }^{6}$ The issue was whether an injunction granted under common law authority prohibiting secondary picketing, infringed s. 2(b). The court formulated two questions: firstly, does the Charter apply to common law; and secondly, does it apply to private litigation? It answered that the Charter does not apply where a private action is governed by the common law. The Charter applies to common law in "public" litigation; it applies to private litigation where a statute or regulation governs; but common law in and of itself does not demonstrate a sufficient connection to government to invoke the Charter's protection. ${ }^{7}$

The primary reason for the decision was a desire to constrain the Charter's application to governmental, rather than private, action. This, the court held, is

2 [1986] 2 S.C.R. 573 [hereinafter Dolphin Delivery].

3 [1994] 3 S.C.R. 835 [hereinafter Dagenais].

1 [1995] 2 S.C.R. 1130 [hereinafter Hill].

5 Another context in which it has been argued that common law violates the Charter is that in Dolphin Delivery, the use of tort law as a basis for anti-picketing injunctions. Reliance on the Charter has been equally unsuccessful in this context: see e.g. Daishowa Inc. v. Friends of the Lubicon (1996), 27 O.R. (3d) 215 (Ont. Div. Ct).

- Supra note 2. The majority decision was written by McIntyre J. and concurred in by Dickson C.J. and Estey, Chouinard and Le Dain JJ. Beetz and Wilson JJ. wrote brief separate concurring decisions, but expressed agreement with the majority position on government action.

7 I use the term "public" litigation here to denote litigation in which there is some additional connection to government. It includes criminal proceedings and other proceedings where government acts more in the capacity of a party, employing common law authority to achieve government purposes: B.C.G.E.U. v. British Columbia (Attorney General), [1988] 2 S.C.R. 214 (injunction to prohibit picketing which might impede access to the courthouse); $R$. v. Swain, [1991] I S.C.R. 933 (common law as applicable in criminal proceedings); United Nurses of Alberta v. Alberla (Attorney General) [1992] 1 S.C.R. 901 (re criminal contempt). Private litigation in which statutes have been subjected to Charter scrutiny include: Re Blainey and Ontario Hockey Association (1986), 26 D.L.R. (4th) 728, 54 O.R. (2d) 513 (C.A.), cited with approval in Dolphin Delivery, at 602; McKinney v. University of Guelph, [1990] 3 S.C.R. 229 [hereinafter McKinney] (human rights legislation governing age discrimination by private employers); and Miron v. Trudel [1995] 2 S.C.R. 418 (insurance legislation governing beneficiaries in private insurance agreements). 
consistent with its constitutional stature ${ }^{8}$ and its text. ${ }^{9}$ Further, there would be significant problems in interpretation and enforcement should the Charter be applied to private action. For example, limits on rights must be "prescribed by law," so might not be imposed by individuals. ${ }^{10}$ Application of Charter provisions to private persons could also restrain individual freedom to an inappropriate degree. $"$

Another policy rationale was that while governmental conduct could effectively be restricted only by constitutional limits, private conduct is regulated by the tort system and by other laws, such as anti-discrimination laws. These laws are better designed for this purpose. They contain more detail as to the appropriate scope of private rights and obligations. They may also include procedural advantages making them more accessible to private parties. For example, the administrative procedure provided under human rights laws is more readily available than a court action for violation of the Charter. To replace utilization of such techniques with Charter actions could create an excessive and unnecessary burden on the courts. ${ }^{12}$

While the Charter does not apply to private action directly, the court acknowledged that it may have a significant indirect effect due to its application to legislation which in turn regulates private relationships. ${ }^{13}$ When, however, private relationships are governed by common law, the Charter does not have the same indirect application.

Why is the common law, or a court order based on the common law, not a sufficient connection to government for Charter purposes? The court's response to this question in Dolphin Delivery was driven primarily by a desire to create limits to the concept of governmental action. Its concern was that a definition of governmental action that included common law or court orders based on common law would widen the scope

Dolphin Delivery, supra note 2 at 593-94, citing P. Hogg, Constitutional Law of Canada, $2 \mathrm{~d}$ ed. (Toronto: Carswell, 1985) at 670-78 and K. Swinton, "Application of the Canadian Charter of Rights and Freedoms" in W.S. Tarnopolsky and G.-A. Beaudoin, eds., The Canadian Charter of Rights and Freedoms: Commentary, 1st ed. (Toronto: Carswell, 1982) 41. The Supreme Court of Canada revisited and reaffirmed its position that the Charter applies to governmental action only in McKinney, ibid. and again referred to the Charter's constitutional status at 262, LaForest J. for the majority, Dickson C.J. and Gonthier J. concurring. Sopinka J. and Cory J. concurred in separate reasons, and Wilson $\mathrm{J}$. and L'Heureux-Dube J. wrote separate dissents, but all indicated agreement that the Charter applied only to governmental action. Wilson J. wrote lengthy reasons on the point, responding to academic criticism of Dolphin Delivery.

Dolphin Delivery, ibid. at 597-98, ref'g to s.32; Swinton, ibid. in a passage quoted by the court (at 595) had also relied on s. 1 and s. 33. See also McKinney, ibid., in which Wilson J., in dissent, but agreeing with the majority that the Charter should be confined to governmental action, referred to ss. $3-4$ and ss. $16-20$ as other provisions of the Charter "clearly aimed at legislatures and governments" at 340 .

10 McKinney, ibid. at 339, Wilson J.

1 Ibid. at 262, LaForest J.; ibid. at 340, Wilson J. This argument is explored in R. Elliot \& R. Grant, "The Charter's Application in Private Litigation" (1989) 23 U.B.C.L.Rev. 459.

12 Dolphin Delivery, supra note 2 at 595, 597, citing Swinton, supra note 8, and A. Mclellan and B. Elman, "To Whom Does the Charter Apply?" (1986) 24 Alta. L. Rev. 361. See also McKinney, ibid. at 263, LaForest J.; ibid. at 340-341, Wilson J.

13 Supra note 7 and accompanying text. 
of Charter application to include virtually all private litigation, and thus all private action:

All cases must end, if carried to completion, with an enforcement order and if the Charter precludes the making of the order, where a Charter right would be infringed, it would seem that all private litigation would be subject to the Charter. ${ }^{14}$

The exclusion of common law in private litigation from the scope of the Charter was also rationalized textually and with reference to the function of the courts in private litigation. The judiciary is not expressly referred to in $s .32$ as a branch of government to which the Charter applies, which opens up the possibility of different treatment of the judicial versus the legislative, executive and administrative branches of government. Further, the court's involvement in private litigation is not as a "contending part[y]," but a neutral arbiter. ${ }^{15}$ This role can be seen as insufficient to bring government into the dispute, as the violator of Charter rights and freedoms.

In Dolphin Delivery and subsequent decisions, all members of the Supreme Court of Canada have agreed that the Charter applies to governmental action only. ${ }^{16}$ I will not dispute that limitation. The justifications reviewed above support the position that this reflects the intended and the sensible scope of the Charter. But the differential treatment of common law and statute law as manifestations of governmental action has been much criticized and never satisfactorily defended. ${ }^{17}$ The textual justification is artificial. Section 32 does not refer to the executive or administrative branches of government expressly, but the Court rightly concluded that these parts of government were included in the generic reference. ${ }^{18}$ In actions subsequent to Dolphin Delivery the court has found "additional" evidence of governmental action where the common law is applied in a criminal context, or in an effort to protect the court's process. In such cases, the exercise by the courts of common law authority has been recognized as

Dolphin Delivery, supra note 2 at 600.

Ibid.

See the references to the various decisions in Dolphin Delivery, supra note 6 and McKinney, supra note 8. See also Lavigne v. Ontario Public Employees Union, [1991] 2 S.C.R. 211 [hereinafter Lavigne], Dagenais (discussed infra), and Hill (discussed infra).

Cory J. for the court in Hill, ibid., discussed below, simply applied Dolphin Delivery, and did not reconsider the issues or provide additional justification for the decision. Wilson $\mathrm{J}$. in McKinney made a significant effort in this regard, but she addressed primarily the need for a distinction between govemmental and private activity, and not the characterization of the common law. The critics include D. Beatty, "Constitutional Conceits: The Coercive Authority of Courts" (1987) U.T.L.J. 183; R. Howse, "Dolphin Delivery: The Supreme Court and the Public/Private Distinction in Canadian Constitutional Law" (1988) U.T. Fac. L. Rev. 248; J. A. Manwaring, "Bringing the Common Law to the Bar of Justice" (1987) 19 Ott. L. Rev. 413; B. Slattery, "The Charter's Relevance to Private Litigation: Does Dolphin Deliver?" (1987) 32 McGill L. J. 905; P. Hogg, "The Dolphin Delivery Case: The Application of the Charter to Private Action" (1987) 51 Sask. L. Rev. 273; Elliot \& Grant, supra note 11; and A. Hutchinson \& A. Petter, "Private Rights/Public Wrongs: The Liberal Lie of the Charter ${ }^{n}$ (1988) 38 U.T.L.J. 288.

Other textual references support application of the Charter to the courts. For example, the legal rights in the Charter apply directly, even primarily, to the courts. Further, the Charter's various references to "law" have been conceded, even in Dolphin Delivery, to include common law. 
"public in nature."19 How can the public or governmental nature of the courts, so obvious in these contexts, be denied when the judiciary creates and applies rules to determine the claims of private litigants? The disputants are private, but the dispute resolution system is public. ${ }^{20}$

The fact that the courts act as arbiters rather than parties should not exclude application of the Charter. The legislature creates rules for the resolution of competing private claims. This legislative function is subject to Charter review. Similarly, courts or others who exercise legislatively-granted discretion in the resolution of private disputes, are governed by the Charter. ${ }^{21}$ The function of the rules or discretionary authority, and the impact on private interests, is relevant to how, but not to whether, the Charter applies. ${ }^{22}$

The reasons for restricting Charter application to governmental rather than private action, do not justify differential treatment of statute and common law. The concern that the imposition of Charter restrictions might unduly limit private actions is not related to a common law/statute law distinction. "Private" actions and relationships are as likely to be governed by statute, as by common law. This is true not only of employment and contractual relationships, where the application of statute law and therefore of the Charter is uncontroversial, but also of family relationships. Where family relationships are governed by legislation, the Charter indirectly applies. For example, it has been argued that freedom of religion should be respected by courts making custody and access orders under the Divorce Act. ${ }^{23}$ The Supreme Court held or assumed that the Charter applied, but took the context into account in considering the nature and degree of any infringement of rights, and the reasonableness of limiting rights. The exclusion of common law from Charter application has been most significant with regard to actions for defamation or to restrain picketing. These "private" actions are not in any way distinguishable from actions regulated by statute and thus indirectly by the Charter. ${ }^{24}$

See the cases referred to supra note 7. These cases are discussed and described as in the text, in Hill, supra note 4 at 1170. Manwaring, supra note 17 at $438-40$.

21 Slaight Communications Inc. v. Davidson, [1989] I S.C.R. 1038 [hereinafter Slaight Communications]. Irwin Toy Ltd. v. Quebec (Attorney General), [1989] I S.C.R. 927 [hereinafter Irwin Toy], discussed infra, notes 68-69 and accompanying text.

23 Young v. Young, [1993] 4 S.C.R. 3. McLachlin J. assumed, without deciding, that the Charter applied and went on to deal with the merits of the constitutional claim. Sopinka J. held that the Divorce Act, R.S.C. 1985 (2d Supp.), c. 3 must be read so as to respect Charter values, citing Slaight Communications, supra note 21, a case in which the Charter was held applicable. L'Heureux-Dube J. alone suggested that the Charter did not apply due to the private nature of the dispute. Nonetheless, she held that courts should uphold Charter values in making decisions under the Divorce Act.

Howse, supra note 17 , proposes a functional distinction between private and public realms of individual behaviour, determined by the suitability of Charter norms as guidelines for individual conduct in the particular context. The private domain would not be subject to Charter review, whether regulated by statute or common law; public activity would be. Elliot \& Grant, supra note 11, characterize private conduct as that within the realm of personal autonomy, "the ability of individual human beings to control their own personal lives," and thus inapplicable to corporate 
The practical difficulties foreseen should the Charter be applied to private action do not arise if the Charter is applied to the common law. Reasonable limits within the common law are "prescribed by law" so that s. 1 creates no particular complications. No alternative tort system would be created; rather the current tort system would be modified to comply with the Charter. Human rights laws and procedures would continue to apply, and would continue to replace recourse to the courts. ${ }^{25}$

The distinction between common law and statute law thus does not forward the purposes of confining Charter review to governmental action. It also ignores the interweaving of common law and statutory law. Statutes may supplement common law. The legislature in enacting such legislation, is effectively ratifying other aspects of the relevant common law. ${ }^{26}$ If a legislature acts to alleviate the harshness of certain aspects of the common law, its efforts will be scrutinized under the Charter. It is illogical to have other, equally or more harsh aspects of the common law immune from review. ${ }^{27}$ The Charter applies and may potentially disable legislative action that seeks to accommodate rights and freedoms, while judicially-created regimes may violate them, and legislatures may approve this situation, and be immune from Charter scrutiny. ${ }^{28}$

How then can a line be drawn between private and governmental action in private litigation? Problems with line-drawing do not arise solely under common law. All forms of governmental action affect private action by what they permit or facilitate, as well as by what they prohibit or mandate. Wherever the effect of governmental action is less than compulsion, complex questions may arise as to the effective cause(s) of an alleged Charter violation. Consider the application of a statute to the terms of a private

entities, particularly large corporations. They also argue that, even with regard to conduct within the realm of personal autonomy, the most sensitive approach would be one that would take into account the interest in personal autonomy along with other interests, not a blanket refusal to apply the Charter.

Bhadauria v. Board of Governors of Seneca College, [1981] 2 S.C.R. 181 held that there is no common law tort of discrimination. Human rights legislation excluded judicial enforcement of the right not to be subjected to discrimination, and required complainants to invoke the statutory procedure. There is no reason to expect that tort law as modified by the Charter would differ in this respect.

Manwaring, supra note 17 at 444.

Slattery, supra note 17 at 919,921 .

This is a reflection of a point made by Hutchinson \& Petter, supra note 17 at 292, that "[t]he effect of limiting Charter application to actions of the legislative and executive branches of government is to exclude from Charter scrutiny the major source of inequality in our society; the maldistribution of property entitlements among individuals." Cass Sunstein has developed this point in the context of American free speech jurisprudence: while it has been recognized in American constitutional jurisprudence since the New Deal period that the enforcement of common law property entitlements is as much a form of government regulation as is the redistribution of those entitlements, this understanding has had little impact in the context of free speech law. In that context, the assumption has generally been that persons have a constitutional entitlement to whatever speech their common law property rights allow them, and that government efforts to redistribute speech entitlements, such as by campaign finance laws, constitute an interference with "freedom" of speech: C. Sunstein, Democracy and the Problem of Free Speech (New York: The Free Press, 1993). 
contract. If the statute mandates the use of a particular term in a contract, any resulting Charter violation is properly ascribed to the statute ${ }^{29}$ But what of statutes that simply permit the inclusion of a term, such as that considered in Lavigne v. O.P.S.E.U., which allowed the parties to a collective agreement to provide for compulsory deduction of union dues from employees' wages? If private parties elect to exercise this option, it can still be argued that the force of the contractual provision, and the source of any resulting infringement of rights or freedoms, is private, not governmental, conduct. ${ }^{30}$ Mere permission or acquiescence by government is not a sufficient indication of governmental action to invoke the Charter." A failure to distinguish between governmental action and inaction (i.e. acquiescence) would deny any content to the former concept. ${ }^{32}$ This need for definitional limits results from complex interrelationships of private and governmental action, not from the source of governmental action. It is not a problem peculiar to the common law; it cannot be avoided by the exclusion of common law from the scope of the Charter; and the challenge which it poses in a common law context is just that - a challenge - and not an insoluble dilemma.

If common law were subjected to Charter review in the same way as statute law there would occur relatively uncontroversial and relatively controversial cases of Charter application. Two leading American decisions illustrate this point. In New York Times v. Sullivan, ${ }^{33}$ the United States Supreme Court held, with little comment either from the court or subsequently from critics, that the common law of defamation was government action, holding that application of the constitution depended not on the "form," but on the "fact" of state power. ${ }^{34}$ That the infringement of freedom of

Miron v. Trudel, supra note 7.

Assuming the parties to the contract are private. If one of the parties is government, as in Lavigne, supra note 16, the contractual provision is the result of an act of government as a contracting party.

Permission must, however, be distinguished from encouragement of private action, which may constitute governmental action for Charter purposes. See Lavigne, ibid. at 247-48, Wilson J.

Legislative omissions and other forms of governmental inaction are subject to Charter challenge in special contexts. Some Charter rights, such as minority language educational rights, expressly impose affirmative obligations on government. Regarding others, it may be that affirmative action by the government might be required to make a right or freedom meaningful: see the discussion in Haig v. Canada (Chief Electoral Officer), [1993] 2 S.C.R. 995. Further, discriminatory omissions should be considered under s. 15: Haig v. Canada (1992), 94 D.L.R. (4th) 1 (Ont. C.A.); contra Vriend v. Alberta, [1996] 5 W.W.R. 617, 132 D.L.R. (4th) 595; see also Native Women's Assn. of Canada v. Canada, [1994] 3 S.C.R. 627. My point is simply that, as a general rule, some distinction must be drawn between governmental action and inaction, for to equate the two would mean that the former is without parameters. Elliot \& Grant, supra note 11 at 484, argue that as a matter of theory, the attempt to define government action and preclude Charter application to private activity, cannot be achieved: "All private relationships are ultimately governed by law, and the state is responsible for the nature and content of the law. Since the Charter applies to the state, the legal regime governing all private relationships must therefore be subject to the Charter."

376 U.S. 254 (1963) [hereinafter New York Times].

Ibid. at 265. L. Tribe, American Constitutional Law, 2d ed. (New York: Foundation Press, 1988) at 1711 , describes the "general proposition that common law is state action" as "hardly controversial," and notes that the Supreme Court has "shown no hesitation whatsoever about subjecting common law defamation and privacy rules to first amendment scrutiny." See also 
expression was seen as emanating from the common law, rather than private action, is not surprising. The common law of defamation essentially prohibits certain forms of expression, by creating liability in damages for their publication. One commentator found it striking not that the Supreme Court found state action in New York Times, but that a lower court had not done so:

[T]he lower court held that the common law of tort, and more particularly libel, was not government action at all, and was therefore entirely immune from constitutional constraint. A civil lawsuit, on this view, is a purely private dispute. The Supreme Court quickly disposed of this objection, and it seems obviously right to have done so. If a court - composed after all of govemment officials - imposes a damages penalty for speech, the state is surely involved. The use of government tribunals to punish speech in this way is conspicuously government action. What is interesting is not the Supreme Court's rejection of the argument, but the fact that the argument could be made by a state supreme court as late as the 1960s. How could reasonable judges think that the judge-made rules of tort law, ordering a newspaper to transfer money, are purely private, and do not regulate speech at all? ?3 $^{35}$

The United States Supreme Court found state action in more controversial circumstances in Shelley v. Kraemer, ${ }^{36}$ where a court order was sought to enforce a racially discriminatory restrictive covenant. In these circumstances it may be argued that any violation of equality rights was caused by private conduct, and that the only government action was the neutral enforcement of a contract. On the other hand, it can be argued that the apparently neutral governmental action was not in fact neutral, if racially restrictive covenants are enforced and other restraints on alienation are held to be unenforceable on public policy grounds. ${ }^{37}$

Clearly, there will be difficult questions raised as to whether the violation of a right or freedom should be ascribed to governmental or private action. The answer will not always be predictable, but will at least arguably forward the purposes of the Charter if it is arrived at after a consideration of the particular right or freedom alleged to have been violated, and the particular governmental action alleged to have effected the violation. ${ }^{38}$ Questions about the relationship of rights violations to private versus governmental action cannot be avoided, ${ }^{39}$ and, particularly in the face of the other arguments referred to above, are not sufficient to justify excluding application of the

Manwaring, supra note 17 at $440-41$ for a discussion of New York Times and Shelley v. Kraemer, 334 U.S. 1 (1948) (below).

Supra note 34.

37 Tribe, supra note 34 at 1714-15. It is interesting that the Charter has had at least an indirect impact in a case analogous to Shelley v. Kraemer: Canada Trust Co. v. Ontario (Human Rights Commission) (1990), 12 C.H.R.R. D/184 (Ont. C.A.), in which a racially discriminatory scholarship trust was held to offend against public policy.

The cases referred to above, in which this issue has arisen in a statutory context, demonstrate this; supra notes 29-32 and accompanying text. P. Hogg, Constitutional Law of Canada, 3d ed. (Toronto: Carswell, 1992) at 34-18 to 34-19, suggests that avoidance of "difficult distinctions to be drawn if a zone of private action is to be shielded from Charter review" is a factor supporting the decision in Dolphin Delivery. For the reasons set out in the text, it is suggested that this is an inadequate rationale for the decision. 
Charter in cases where the connection between the law (governmental action) and the infringement of a particular right is clear.

\section{THE CHARTER AND DEVELOPMENT OF THE COMMON LAW}

After concluding that the Charter does not apply to common law in the context of private litigation, the Court in Dolphin Delivery added that the Charter would nonetheless affect the common law, because the judiciary should apply and "develop the principles of the common law in a manner consistent with the fundamental values enshrined in the Constitution. ${ }^{140}$ This statement perhaps more than any other indicates the weakness of the reasoning in the case. If a purposive inquiry dictated that the Charter should not apply in this context, it would also indicate that Charter values are not relevant. ${ }^{41}$ That the Court felt compelled to recognize the relevance of Charter values demonstrates that it was not fully comfortable with its prior holding as to the scope of Charter application.

Apart from the questionable principle involved, the significance of the direction to develop the common law in accordance with Charter values is ambiguous. What kind and how much of an impact is the Charter to have? Is the process different from application of the Charter? These questions were not answered in Dolphin Delivery. While the Court held that the proscription of secondary picketing by the common law was consistent with the Charter, it also concluded in dicta that a prohibition of secondary picketing in the labour context would be justified under s. 1, so that the result would have been the same in the face of a statutory proscription.

It can be argued as a matter of logic that a reference to Charter values should be less robust than an application of the Charter, or the major premise of Dolphin Delivery would be meaningless. Peter Hogg has suggested that an approach of this nature would be most consistent with the ratio of Dolphin Delivery. ${ }^{42}$ The Supreme Court of Canada has now adopted this approach in Hill v. Church of Scientology, relying on such logic, and also on its earlier discussion of the relationship of Charter values and the common law in $R$. v. Salituro. ${ }^{43}$

In Salituro, the Supreme Court of Canada described the duty to develop the common law of spousal privilege in accordance with Charter values as an aspect of the court's general power to change the common law, which it held to be confined to "incremental changes ... to bring legal rules into step with a changing society" and not "complex changes ... with uncertain ramifications" which should be left to the legislature. ${ }^{44}$ But Salituro was a criminal case in which the Charter would normally apply, even with

Supra note 2 at 603.

In Bank of British Columbia v. Canadian Broadcasting Corp. (1995), 40 C.P.C. 353 (B.C.C.A.) at 388, issued prior to the Supreme Court of Canada decision in Hill, Hutcheon J.A. indicated an inability to "develop a meaningful distinction between the application of the Charter and the application of Charter values." See also Slattery, supra note 17.

Hogg, supra note 17 at $278-79$.

[1991] 3 S.C.R. 654 [hereinafter Salituro].

Ibid. at 670-71. 
regard to the common law. The reason it did not, was that it was not argued that the common law relating to spousal testimonial incompetence infringed anyone's Charter rights. Had the accused's rights been affected, the Charter would clearly have applied. If a spouse's security of the person were compromised, or equal access to the justice system denied, again the Charter would likely apply to the common law in this criminal context. Apparently none of these possibilities was raised by the facts or in the argument. The Charter discussion in Salituro was in general terms, referring to concepts of freedom and individual choice as values underlying the Charter, ${ }^{45}$ not as rights or freedoms guaranteed by it. In summary, the Charter did not apply because of the nature of the common law rule and the content of Charter rights, not because of a lack of governmental action.

Just a few months before the Hill decision, in Dagenais v. Canadian Broadcasting Corp., it seemed that the Supreme Court of Canada might be prepared to equate the processes of developing the common law in accordance with Charter values and application of the Charter. The case involved a challenge to a publication ban, granted in an effort to protect the right to a fair trial of criminal charges. ${ }^{46}$ That the Charter should apply was agreed by all of the justices, although for different reasons. ${ }^{47}$ The majority ${ }^{48}$ implicitly seemed to be ready to overrule Dolphin Delivery. Lamer C.J. stated that courts may rely on statutory or common law discretionary authority when granting publication bans, and that the Charter should apply to the exercise of the discretion, regardless of its source. Similarly, just as a statute which mandates the

Ibid. at 673.

See supra note 3. The ban issued against the documentary "The Boys of St. Vincent," a fictional account of child sexual abuse in a Catholic institution in Newfoundland, because of its perceived interference with the right to a fair trial of four members of a Catholic religious order charged with abuse of boys under their care in schools in Ontario. The court held that the ban violated the Charter's protection of freedom of expression.

Ibid. McLachlin J., in a concurring judgment, criticized the majority approach to the application of the Charter for implicitly overruling Dolphin Delivery, at least where the common law grants discretionary power, and potentially with regard to all court orders based on the common law. She agreed that the Charter should apply, but limited its application to the criminal context. She reviewed previous decisions in which the Charter was applied to common law rules or orders based upon them, and concluded that, while the application of the Charter to court orders should be considered on a case-by-case basis, "at a minimum" all "[c]ourt orders in the criminal sphere which affect Charter rights or the ability to enforce them are themselves subject to the Charter": ibid. at 944. La Forest J., dissenting on other grounds, approved McLachlin J.'s remarks and held that the case was distinguishable from Dolphin Delivery and the order reviewable under the Charter because it was "exercised pursuant to a discretionary power directed at a governmental purpose, i.e., ensuring a fair trial": ibid. at 893 . Gonthier J., dissenting on other grounds, also held that the judge's order, because it dealt with the determination of the rights of accused persons in criminal matters, was subject to the Charter: ibid. at 918. L'Heureux-Dube J., dissenting, alone held that this was not a case in which the Charter should be applied to the court order. However, she agreed with the majority that the common law should be developed in accordance with the Charter, concluding that "[w]hile the publication ban is not subject to the Charter, the common law governing its issuance is subject to Charter scrutiny": ibid. at 912 . Whether she intended this to be some limited form of Charter review is not clear. 
issuance of a publication ban is directly subject to a Charter challenge, so would be a common law rule mandating a ban. ${ }^{49}$

Lamer C.J. went on to reformulate the common law, or apply the Charter to the court order authorizing the publication ban. He described the process in both ways, drawing no distinction. ${ }^{\text {so }}$ The process thus employed was not subjected to any limits external to the Charter, such as those suggested in Salituro. He held that a publication ban could be ordered only where it would meet a standard which "clearly reflects the substance of the Oakes test applicable when assessing legislation under s. 1 of the Charter" (emphasis added). ${ }^{51}$ The Charter was applied essentially as it would have been to legislation or an order granted pursuant to legislative discretion.

As discussed by the other justices, the majority reasoning is inconsistent with Dolphin Delivery. As sensible as it may seem, the majority's broad approach to Charter application is incorrect as an interpretation of developed Charter doctrine. ${ }^{52}$ Viewed in light of Hill, Dagenais is now best seen as an instance of application of the Charter to the common law where an additional connection to government was present in that the proceedings were related to the provision of a fair criminal trial. ${ }^{53}$

In Hill v. Church of Scientology, defendants to a defamation action sought to raise the Charter, alleging that the common law of defamation unreasonably restricted free expression. The Supreme Court of Canada reconfirmed the rule laid down in Dolphin Delivery and held that the Charter could not be "applied directly to scrutinize the common law of defamation" in private litigation. ${ }^{54}$ Nonetheless, the Court agreed that common law principles should be developed in light of the values underlying the Charter. But for the first time the Court elucidated the distinction between application of the Charter and development of the common law in accordance with Charter values. Where there is additional governmental action and the Charter is applied to common law, the analysis will be similar to that which applies to legislation. In private litigation

Ibid. at $874-75$.

so Ibid. at 875,878 . In the other judgments in the case, McLachlin J. preferred the latter characterization and L'Heureux-Dube J. preferred the former.

51 Ibid. at 878 [emphasis added].

52 The more accurate description of the application of the Charter to the common law is found in the concurring judgment of McLachlin J. and the dissenting judgments of LaForest J. and Gonthier, J. described supra note 47 . The statement of LaForest J. that the Charter applies to court orders based on common law authority that are "directed at a governmental purpose, i.e., ensuring a fair trial": ibid. at 893 perhaps comes closest to the subsequent statement in Hill, that the Charter applies where there is governmental action, commonly in the criminal sphere, but also in the civil sphere where the court is considering matters "essentially public in nature": supra note 4 at 1170 . The applicability of Dagenais and the Charter to publication bans issued in a civil context is uncertain. A governmental purpose, such as the securing of a fair civil trial, could be involved. Where a publication ban is sought for a private purpose, such as the protection of confidential information, it would seem that neither the Charter nor Dagenais would apply. employment as a Crown prosecutor, but he brought the suit as a private person and not in his public capacity. The court held that the litigation was essentially private. 
a different approach is called for because "[i]t is important not to import into private litigation the analysis which applies in cases involving government action." ${ }^{.55}$

The distinction drawn by the Court was premised upon the legitimacy of the Dolphin Delivery distinction, which was not revisited or considered in the context of defamation law. The only authority referred to as an example of Charter values informing common law development was Salituro. As discussed earlier, and as acknowledged by the Court in Hill, no clearly articulated right or freedom was infringed by the common law rule in Salituro. ${ }^{56}$ There is nothing in this framework to ensure that the outlined distinction responds to differences in the contexts in which the two approaches will be employed. Indeed, contextual differences did not appear to be the concern of the Court. The true rationale appears to be the desire to give substance to the line drawn in Dolphin Delivery:

Private parties owe each other no constitutional duties and cannot found their cause of action upon a Charter right. The party challenging the common law cannot allege that the common law violates a Charter right because, quite simply, Charter rights do not exist in the absence of state action. The most that the private litigant can do is argue that the common law is inconsistent with Charter values. It is very important to draw this distinction between Charter rights and Charter values. Care must be taken not to expand the application of the Charter beyond that established by s. 32(1), either by creating new causes of action, or by subjecting all court orders to Charter scrutiny. Therefore, in the context of civil litigation involving only private parties, the Charter will "apply" to the common law only to the extent that the common law is found to be inconsistent with Charter values."

The Court identified three ways in which the process of considering "Charter values" is to differ from applying "Charter rights." Firstly, the courts are cautious when amending the common law generally, and when considering Charter values should act similarly and "not go further than is necessary.... Far-reaching changes to the common law must be left to the legislature." ${ }^{18}$ If this means nothing more than dealing with changes in an incremental manner, it is not problematic. But taken literally, this rule would lead to a result contrary to common sense. In effect, it stipulates that the court has authority to cure minor transgressions, but not egregious violations.

Secondly, a traditional s. 1 analysis or its equivalent is not to be utilized. Balancing must be more flexible than under s. 1. "Charter values, framed in general terms, should be weighed against the principles which underlie the common law. The Charter values will then provide the guidelines for any modification to the common law which the court feels is necessary." ${ }^{.59}$ This reflects the Salituro approach, as earlier described by

Ibid. at $1169-70$.

When first referring to Salituro, Cory J. noted: "Unlike the present appeal ... the common law rule in Salituro was not alleged to infringe a specific Charter right," ibid. at 1167. However, when he went on to differentiate Charter application and development of the common law in accordance with Charter values, this distinction was ignored. See also text accompanying notes 42 and 43 . Ibid. at $1170-71$.

Ibid. at 1171.

Ibid. 
the Court. ${ }^{60}$ Cory J. did not distinguish the case, as he had earlier, and in support of this broad balancing approach noted only that, "It must be remembered that the Charter "challenge" in a case involving private litigants does not allege the violation of a Charter right." ${ }^{61}$ But in Hill, as previously acknowledged by Cory J., ${ }^{62}$ the allegation was most certainly that a Charter right had been infringed. To describe the allegation as otherwise amounts to no more than a repetition of the position that the two categories of cases, those involving Charter application and those involving development of the common law, are to be distinguished. It does not in any way premise the distinction on real differences between the cases in each category.

The third distinction described by the Court was that there should be no onus shift as occurs under $\mathbf{s}$. 1. The party challenging the common law bears the "onus of proving both that the common law fails to comply with Charter values and that, when these values are balanced, the common law should be modified." ${ }^{63}$ This is the only one of the three rules that was expressly based on the nature of private litigation:

[W] here government action is said to violate a Charter right, it is appropriate that the government undertake the justification for the impugned statute or common law rule. However, the situation is very different where two private parties are involved in a civil suit. One party will have brought the action on the basis of the prevailing common law which may have a long history of acceptance in the community. That party should be able to rely upon that law and should not be placed in the position of having to defend it. It is up to the party challenging the common law to bear the burden of proving not only that the common law is inconsistent with Charter values but also that its provisions cannot be justified. ${ }^{\text {at }}$

A different approach to onus does seem to be justified here. This different approach is also justifiable as compared with private litigation in which a statute is challenged. The government has an obvious interest in maintaining the validity of its statutes and regulations, ${ }^{65}$ as well as a particular ability to access and present pertinent evidence. Neither of these factors is necessarily present in the case of the common law.

Thus the first two distinctions listed by the Supreme Court of Canada are not responsive to contextual differences between private litigation governed by common law and other actions in which Charter challenges might arise. The third however, is a justifiable reaction to such differences. Are any other procedural or analytical distinctions warranted? One may be found by returning to Dolphin Delivery and the reasons given therein for holding that courts and common law did not provide a sufficient connection to government in otherwise private litigation. The role of the

Ibid. at 1167, where Cory J. described the analysis in Salituro as different than that undertaken under $\mathbf{s .} 1$ and involving balancing, "in a broad and flexible manner, the conflicting values."

Ibid. at 1171 [emphasis added].

lbid. at 1167 . See supra note 56.

Ibid. at 1171 .

Ibid. at 1171-72.

See Hogg, supra note 38 at 56-19, 56-20. This interest accounts for statutory provisions requiring notice to the Attorney General or Minister of Justice where a statute or regulation is challenged, and granting a right to intervene is such cases. The provisions are referred to by $P$. Hogg. 
courts as arbiters of disputes was distinguished from the role of the courts in pursuing governmental objectives. It has already been argued that judicial action for either purpose is an action of government, and that the Charter should apply. ${ }^{66}$ Nonetheless, the particular function being exercised by the court is a circumstance relevant to the manner of application of the Charter. The Supreme Court of Canada has held repeatedly that the balancing process involved under s.1 must be flexible and responsive to context. A pertinent aspect of the context is whether the government has acted as an adversary or a mediator. Where "government is best characterized as the singular antagonist of the individual whose right has been infringed," ${ }^{67}$ as in the prosecution of crime, a relatively stringent application of the Oakes test is required. But where government acts to balance "the claims of competing groups," and particularly where it seeks to protect vulnerable groups, a more flexible approach should be employed. ${ }^{68}$ The justifications for this relate to the comparative institutional competence of judicial and legislative bodies, and to the Charter's concern with disadvantaged groups. Some degree of uncertainty or controversy in these decisions is unavoidable, and the courts should hesitate to upset an assessment which has had the advantage of an open-ended legislative process, and bears the imprint of democratic legitimacy. Further, it would be inconsistent with the underlying objectives of the Charter to "roll back legislation which has as its object the improvement of the condition of less advantaged persons. ${ }^{169}$

Where a court is considering common law, none of the concerns as to relative institutional competence arise. ${ }^{70}$ The appropriate balance of competing claims will still frequently be disputable, but it must be recalled that the court is reconsidering an earlier court ruling. There is no fear of upsetting the democratic process where the legislature has not acted or has merely acquiesced in a common law rule. The established law has the advantage that it reflects settled expectations, but that is addressed by placing the onus on the challenger. " However, the concern with regard to the impact of change on disadvantaged or vulnerable persons or groups remains. Common law, like statutory law, may protect those who need protection, and this function should be scrupulously respected, even in the face of competing constitutional rights. ${ }^{72}$

See the discussion supra notes 20-22 and accompanying text.

Edwards Books and Art Lid. v. The Queen, [1986] 2 S.C.R. 713 at 779 thereinafter Edwards Books].

Ibid:; and Irwin Toy, supra note 22 at 993.

Edwards Books, ibid. at 779.

$R$. v. Swain, supra note 7 at $983-84$.

Supra notes 63-64 and accompanying text.

Statutory provisions aimed at the protection of children were upheld in B.(R) v. Children's Aid Society of Metropolitan Toronto, [1995] I S.C.R. 315 (wardship order under provincial legislation to permit blood transfusion to the administered to an infant over religious objections of parents) and Young v. Young, supra note 23 (Divorce Act requirement that custody and access orders be made in the best interests of the child held not to violate parents' religious freedom or other Charter rights). A court relying on its parens patriae jurisdiction should adopt a similar approach to a Charter challenge; not excluding a Charter claim but with great respect for the child's countervailing entitlement to protection. 
In summary, because of contextual distinctions, development of the common law in accordance with Charter values, as opposed to application of the Charter, should not involve an onus shift and should employ a more relaxed application of the s. 1 test in those cases in which the common law protects vulnerable persons. The Oakes test is also applied flexibly where statutory law protects vulnerable persons, so that the only unique feature called for by this context is the lack of an onus shift. Other differences are artificially imposed. This approach does not violate the essential holding of Dolphin Delivery, that the Charter does not apply directly to private action. ${ }^{73}$ It is also consistent with the direction that the judiciary should develop the common law in accordance with Charter values. Dolphin Delivery does not require a less rigorous respect for Charter rights and freedoms in this context. Indeed, what could be a clearer indication that the common law is inconsistent with fundamental constitutional values than a demonstration that the common law violates a Charter right or freedom and does not meet the s. 1 test? As compared with the somewhat amorphous discussion of Charter values in Salituro, this would seem to be a more convincing demonstration.

Of course, the Supreme Court of Canada went considerably further than this in distinguishing application of the Charter and development of the common law in accordance with Charter values. I will now continue with the decision in Hill, and argue that the Court went so much further that there was no meaningful consideration of the impact of defamation law on free expression.

\section{DEFAMATION LAW AND THE CHARTER}

Having determined that the common law of defamation should be developed in accordance with Charter values, the Supreme Court of Canada had to consider whether any change in the law was called for in the circumstances of Hill's claim. The trial jury had found and the Ontario Court of Appeal had affirmed that both the Church of Scientology and its counsel had defamed Casey Hill by describing to the press allegations made in judicial proceedings for criminal contempt. ${ }^{74}$ The jury award of $\$ 1.6$ million was also upheld by the Court of Appeal. ${ }^{75}$ The Supreme Court of Canada

It would be necessary for a challenger to establish that any rights infringement was caused by the common law or court order applying it; see the discussion, supra notes 33-38 and accompanying text. With this approach, the problems of direct application to private action are avoided, supra note 25 and accompanying text.

(1994) 18 O.R. (3d) 385, 114 D.L.R. (4th) I (C.A.), affirming a judgment of the Ontario Court of Justice (General Division). Manning spoke to the media including television media from the steps of Osgoode Hall. He was appearing in court on an unrelated matter, and was wearing a barrister's gown. He described contempt proceedings that he was initiating on the Church's behalf, which alleged that Hill had participated in misleading the court and in giving access to documents sealed by court order: Hill, supra note 4 at 1147 .

This was comprised of $\$ 300,000$ general damages (assessed against both Scientology and Manning), $\$ 500,000$ aggravated damages (against Scientology only) and $\$ 800,000$ punitive damages (against Scientology only). There were various factors contributing to the damage amount. The evidence at trial was that the Church's own investigation had indicated that the allegations made against Hill were not true, and that the Church was aware of this at least prior to the contempt trial. The allegations were nonetheless maintained throughout the contempt proceedings (which were dismissed), and in the subsequent defamation action brought by Hill. In 
upheld the lower court decisions, concluding that the common law of defamation, "in its application to the parties in [the] action," complied with Charter values and did not require amendment. ${ }^{76}$ The Court's discussion of Charter values bore little resemblance to Charter analysis in other cases.

The consideration of the Charter commenced with a brief recognition that "freedom to express ideas and to criticize the operation of institutions and the conduct of individual members of government agencies" is important, so important that without it "democratic forms of government would wither and die." discussion related to the reasons for limiting free expression, and to the high value of individual reputation as a counterbalance to free expression. Free expression was found wanting in the balance by a significant margin. The lack of weight assigned to it is completely out of line with previous Charter jurisprudence.

\section{For example, Cory J. stated:}

Certainly, defamatory statements are very tenuously related to the core values which underlie s. 2(b). They are inimical to the search for truth. False and injurious statements cannot enhance selfdevelopment. Nor can it ever be said that they lead to healthy participation in the affairs of the community. Indeed they are detrimental to the advancement of these values and harmful to the interests of a free and democratic society. ${ }^{78}$

This treatment of erroneous expression, where errors may be innocently made, ${ }^{79}$ contrasts startlingly with the Court's assessment of the potential value of wilful falsehoods in $R$ v. Zundel. ${ }^{80}$ That case dealt with s. 181 of the Criminal Code, which prohibited the publication of news or statements "known to be false" and "likely to cause injury or mischief to a public interest." The majority judgment of McLachlin J. concluded that even deliberate falsehoods might play a justifiable role in a political debate, and that they further deserved constitutional protection because of the difficulty of assessing whether a statement is true or false. ${ }^{81}$ Injurious statements about public

fact the Church's plea of justification was withdrawn only on the first day of appeal before the Ontario Court of Appeal, in 1993, nine years after the defamatory statement. Scientology also continued to impugn Hill's character in other ways during the trial and in other contexts. Manning also pleaded justification but withdrew the plea a week before the trial: ibid. at 1204, 1207, 1210 . lbid. at 1188.

Ibid. at 1172.

Ibid. at 1174.

Truth, or "justification" is a defence to a defamation action, likely because "as a matter of policy, the law has decided to protect free speech over the right to reputation, where material which damages reputation is true, no matter why it is published, and no matter how unfair this may be to the person defamed": L. Klar, Tort Law, 2d ed. (Toronto: Carswell, 1996) at 565. But it is truth as proved in the defamation action, not as believed by the defendant at the time of publication, that is pertinent. A defendant who makes an error as a result of negligence, or who makes an error despite all reasonable care, or who does not make an error but is unable to prove the truth of the defamatory statement, is nonetheless liable.

1I Ibid. at 754. Truth is not always difficult to ascertain. Indeed, the holocaust denial which was the subject of Zundel was clearly false. But a law which penalizes false statements risks overbreadth in other situations where the assessment is difficult. 
officials are obviously an essential part of criticism of "the conduct of individual members of government agencies," which is patently of fundamental value in a democratic society and central to the guarantee of free expression. ${ }^{82}$ That such criticism may contain factual errors cannot deprive the activity of its essential value. Injurious errors cause harm, which creates a counterbalancing interest, but does not justify depreciation of the value of this type of expression.

The minimal value attributed to expression in Hill was contrasted with the great value accorded to reputation, which was given a quasi-constitutional stature as a reflection of interests in individual dignity and privacy ${ }^{83}$ It is not surprising that the protection of reputation justifies incursions on free expression, but the way in which the interest was extolled is surprising. The Court discussed the historical protection of reputation, including punishment for libel under Roman law that varied from "the loss of the right to make a will, to imprisonment, exile for life, or forfeiture of property."184 It went on to consider Star Chamber jurisdiction over libel, assumed in an effort to eradicate duelling, and the 1605 case of De Libellis Famosis penalizing libel because of its potential to incite a breach of the peace, regardless of whether or not the libel was published to a third person, or was true. The Court concluded that "[t]he character of the law relating to libel and slander in the 20th century is essentially the product of its historical development up to the 17 th century, subject to a few refinements...." ${ }^{85}$ This history was not taken as evidence that the law, which "no longer serves as a bulwark against the duel and blood feud," ${ }^{186}$ may be outdated and in need of modernization to bring it into line with Charter values, but rather as an indication of the fundamental importance of the interest in individual reputation. Again, the contrast with Zundel is startling. In that case the historical antecedents of s. 181 of the Criminal Code were traced to the Statute of Westminster of 1275, at which time its primary aim was the prevention of statements about powerful landowners that might lead them to resort to arms in response. The majority held that, with such origins, the law either did not serve at all or was insufficiently related to any substantial government objective today. There are obvious distinctions in the two cases, as the common law of defamation has developed and retained a degree of significance not shown with respect to s. 181, but the uncritical reference to archaic aspects of the law of defamation is one of many features that makes it clear that Charter values played an extremely small role in the Hill judgment.

It had been argued that the common law of defamation should be modified by adopting the American malice rule applicable to defamation of public officials since the case of New York Times v. Sullivan. ${ }^{87}$ The Court cited American academic and judicial

Hill, supra note 4 at 1172. The connection between criticism of govemment officials and participation in social and political decision-making, identified in Ford v. Quebec (Attorney General), [1988] 2 S.C.R. 712 and Irwin Toy, as one of the fundamental values underlying s. 2(b), is obvious.

83 Hill, ibid. at 1179 .

a Ibid. at 1176.

ss Ibid. at 1177.

8 Ibid. at 1178.

7 Supra note 33. 
criticism of the malice standard, without noting that these critics did not advocate a return to the pre-New York Times state of the law. Some suggested that there should be an absolute bar of libel actions by public officials; others argued for more judicial enforcement of the New York Times rule through summary dismissals; yet others argued for a new approach, such as declaratory actions in which the sole issue would be the truth of the statement, or limitations on recoverable damages. ${ }^{88}$ Explicitly or implicitly, all acknowledge that the state of the common law prior to New York Times did not given adequate scope for free expression.

The Court also cited the House of Lords decision in Derbyshire County Council v. Times Newspapers Ltd. ${ }^{89}$ and the Australian High Court in Theophanous v. Herald and Weekly Times Ltd., ${ }^{90}$ as examples of refusals to follow the New York Times approach. The Court did not indicate that in each of these decisions, even in the absence of an express constitutional protection of freedom of expression, the highest courts of the United Kingdom and Australia recognized that the common law of defamation may unduly hinder free expression. ${ }^{91}$ The Australian High Court made a significant move in the direction of the New York Times rule, with regard to publications about government and political matters, including material concerning the performance in office of members of Parliament, and the suitability of persons for office as members of Parliament. Under the modified common law rule, such a publication is not actionable if the defendant believed the publication to be true and was not reckless as to whether it was true or false, and if the publication was reasonable in the circumstances, in that steps were taken to check its accuracy or it was otherwise justified. ${ }^{92}$

In concluding that the Canadian law of defamation should not be modified by incorporating the New York Times malice standard, Cory J. claimed:

I simply cannot see that the law of defamation is unduly restrictive or inhibiting. Surely it is not requiring too much of individuals that they ascertain the truth of the allegations they publish. The law

E.g. A. Lewis, "New York Times v. Sullivan Reconsidered: Time to Return to "The Central Meaning of the First Amendment"" (1983) 83 Colum. L. Rev. 603 called for constitutional limits on damage awards, a ban on punitive damages and more active judicial enforcement of New York Times, to achieve a true vindication of the New York Times, a "thrilling case" which protects the function of the "citizen-critic of government." P. Leval, "The No-Money, No-Fault Libel Suit: Keeping Sullivan in its Proper Place" (1987-88) 101 Harv. L. Rev. 1287 suggested the approach indicated in the title. Even Epstein in R.A. Epstein, "Was New York Times v. Sullivan Wrong?" (1986) 53 Univ. of Chicago L.R. 782, who did suggest a return to strict liability, would accompany this with damage limits. Justice White in the dissenting judgment in Dun \& Bradstreet, Inc. v. Greenmoss Builders, Inc., 472 U.S. 749 (1985), which was quoted at length in Hill, supra note 4 at 1184-85, also advocated limitations on damages as an alternative to the New York Times malice standard. [1993] 1 All E.R. 1011 [hereinafter Derbyshire]. (1994), 124 A.L.R. 1 [hereinafter Theophanous].

In Derbyshire, supra note 89 , the House of Lords held that under common law a local authority did not have the right to maintain a defamation action, because of the public interest in uninhibited public criticism of governmental bodies.

Theophanus, supra note 90 at 23, 26, 63 . 
of defamation provides for the defences of fair comment and of qualified privilege in appropriate cases.

Those who publish statements should assume a reasonable level of responsibility. ${ }^{93}$

This statement gives no regard to the limitations on the applicability of the defences of fair comment and qualified privilege, ${ }^{94}$ or the chilling effect of the law as found by courts in the United States, the United Kingdom and Australia. ${ }^{95}$ It further ignores a factor given significance both by the Australian High Court in Theophanous and by the Supreme Court of Canada in Dagenais, that despite some degree of balancing in the common law, the judges who developed it were not concerned with freedom of expression in a constitutional sense and did not give it adequate weight in the balancing which was attempted. ${ }^{96}$

The Court's conclusion was rather carefully framed:

In conclusion, in its application to the parties in this action, the common law of defamation complies with the underlying values of the Charter and there is no need to amend or alter it."7

This is an indication that many issues remain for another case. While the malice standard seems unlikely to be accepted, some form of negligence standard might be adopted. But Hill will pose barriers to the reconciliation of defamation law and free expression. Its approach to the consideration of Charter values minimizes the role of the Charter with regard to a part of our law that has maximal impact on free expression. Future litigators seeking to develop the common law of defamation in view of Charter values will face the many one-sided pronouncements as to the lack of value of defamatory expression and the quasi-constitutional significance of personal reputation. Any future challenge to defamation law will face major obstacles. ${ }^{98}$

Hill, supra note 4 at 1187 .

The defence of fair comment is available only if a number of conditions are met, including the requirement that the comment be in the form of an opinion based on true facts. The several conditions and the Canadian courts' generally conservative approach to the defence are reviewed in Klar, supra note 79 at 579-85. The defence of qualified privilege applies when a defendant had a duty or interest to convey material to a particular person. The Supreme Court of Canada has not recognized a duty or interest in the press or in interested citizens to convey to the public information about, for example, government officials or political or social issues. See the discussion in Klar, ibid. at 569-79, especially 573-74.

The Supreme Court of Canada in Hill, criticized the lack of "any evidentiary basis upon which to adjudicate [the] constitutional attack": ibid. at 1163, repeating a criticism of the Ontario Court of Appeal which had called for "[a]t a minimum, some form of evidence ... to prove that libel chill exists which prevents publication of true comments in media reports and elsewhere": supra note 74 at 27 (D.L.R.). On the other hand, the Supreme Court of the United States, the House of Lords and the High Court of Australia were prepared to infer a libel chill: New York Times, supra note 33 at 279; Derbyshire, supra note 89 at 1018; Theophanus, supra note 90 at 19.

Theophanous, ibid. at 19.

Hill, supra note 4 at 1188 [emphasis added].

Bank of British Columbia v. Canadian Broadcasting Corp., supra note 40, leave to appeal to S.C.C. dismissed April 25, 1996, is another unsuccessful effort to alter the common law of defamation through reference to the Charter. 
A comparison of Hill with cases challenging criminal defamation provisions demonstrates the difference in perspective brought about by Charter application. Several recent decisions have dealt with the defamatory libel sections of the Criminal Code. The Code defines defamatory libel as "a matter published, without lawful justification or excuse, that is likely to injure the reputation of any person by exposing him to hatred, contempt or ridicule, or that is designed to insult the person of or concerning whom it is published." ${ }^{199}$ Section 300 prohibits the publication of defamatory libel known to be false, providing a maximum sentence of five years' imprisonment. Section 301 prohibits the publication of defamatory libel without any qualification as to known falsity, providing for a maximum of two years' imprisonment. Limited defences are provided relating to statements that are true or reasonably believed to be true and published for the public benefit. ${ }^{100}$

In the decisions to date courts have tended to conclude that s. 300 is a reasonable and justifiable limit on free expression, but that s. 301 is unconstitutional; in other words, while malicious defamation may be penalized, to take the same approach to negligent or innocent falsehoods would be unreasonable. ${ }^{101}$ The courts have been

Criminal Code of Canada, R.S.C. 1985, c. C-46, s. 298.

Section 309 provides a defence where a defamatory matter is "on reasonable grounds" believed to be true, and is "relevant to a subject of public interest, the public discussion of which is for the public benefit." Section 311 makes truth a defence, provided the publication and the "manner in which it was published" are for the public benefit. Section 310 exempts from the offence fair comments on public communications and on the "public conduct" of persons involved in "public affairs." There is comment on these defences, particularly on the limited role of truth as a defence, having regard to the historical purpose of criminal libel law (prevention of breach of the peace), in $R$. v. Stevens (1995), 96 C.C.C. (3d) 238 (Man.C.A.) at 247-48, Scott C.J.M. and at 288-93, Twaddle J.A. [hereinafter Stevens].

Section 301 was held to be unconstitutional in R. v. Gill, [1996] O.J. No. 1299 [hereinafter Gill]. The accused had displayed posters bearing pictures of Kingston penitentiary guards and the words:

The suspect is one of several people wanted in connection with the kidnap, torture and killing of Robert Gentles on October 24, 1993. The six are believed to be members of a criminal gang operating in the Kingston area. If you see the suspects or have information as to their whereabouts, notify the Kingston Police at 544-5000 or 549-4660. Caution, do not attempt to apprehend the suspects yourself. They have a long history of sadistic violence and are believed to have socio-pathic tendencies. VIGILANCE IS EVERY CITIZEN'S DUTY.

Section 300 was upheld in Slevens, rev'g [1994] 6 W.W.R. 636, which rev'd [1993] 7 W.W.R. 38, 82 C.C.C. (3d) 97. Notice of appeal to the S.C.C. was filed March 23, 1995; Court File No. 24626. The facts were summarized by Scott C.J.M. in the appeal decision at 244:

[T]he accused and the complainant had a brief relationship during the summer of 1991 . After the complainant ended the relationship, the accused displayed a number of posters in the university centre and education buildings on the University of Manitoba campus. At the time, the complainant was a student in the Faculty of Education. These posters had a picture of the complainant and described her, among other things, as being desperate, suicidal and claimed that she had had an abortion. Shortly after these posters appeared at the university, the accused placed another poster in the mailbox of two of the complainant's neighbours. This second poster, which also included the complainant's picture, described her as a known sex offender.

Section 300 was also upheld in $R$. v. Lucas (1996), 104 C.C.C. (3d) 550 (Sask.C.A.) [hereinafter Lucas], affg 31 C.R.R. (2d) 92 (which further struck down s. 301; this aspect of the decision was not appealed). Application for leave to appeal was filed March 4, 1996 (Court File No. 25177). 
unanimous that the Charter applies, and that the interests in privacy and reputation which the statutory provisions seek to protect ${ }^{102}$ must be balanced against interests in free expression. This process has been undertaken notwithstanding that the expression resulting in the charge has been no more and in some circumstances much less clearly related to s. 2(b) values than that involved in Hill. ${ }^{103}$

It cannot be denied that the common law of defamation has a significant impact on expression, including expression that is central to the s. 2(b) guarantee. Not only American courts have recognized this. The House of Lords and the Australian High Court, even in the absence of an express constitutional guarantee, concluded that defamation law inhibits free expression. The High Court referred specifically to Dolphin Delivery and Canadian defamation cases. A majority of the Court essentially disapproved the Canadian approach, holding that constitutional protection of free expression must extend to defamation law, including common law, in order to achieve its underlying purpose:

To our minds, it is incontrovertible that an implication of freedom of communication, the purpose of which is to ensure the efficacy of representative democracy, must extend to protect political discussion from exposure to onerous criminal and civil liability, if the implication is to be effective in achieving its purpose. ${ }^{104}$

It can, of course, be argued that the defamation laws of the States do not curtail freedom of political communication or discussion in that, subject to limited exceptions, they do not forbid publication under criminal sanction but merely impose civil liability.... [H]owever, ... it is now well settled that, in the application of constitutional guarantees or immunities, one must look to substance rather than form. When that is done, it is apparent that potential civil liability in damages and costs is likely to represent a much more effective curtailment of the freedom of political communication and discussion that the possibility of conviction of most of the many criminal offences which are punishable by a pecuniary penalty. ${ }^{105}$

The Charter has been raised in response to defamation actions brought by politicians and governmental officials. The public interest in permitting free expression about the issues under discussion is self-evident. As noted, Hill related to criticism of a prosecutor for conduct involved in the performance of his duties. The leader of a

The facts were:

On September 20, 1993 at 9:00 a.m. the accused were observed to be walking on a public sidewalk in front of the Police Station in Q, Sask. carrying a sign which had printed on one side the words "Did (rank) [police officer] just allow or help with the rape/sodomy of an 8 year old" and on the other side the words "if you admit it [the police officer] then you might get help with your touching problem": Lucas (1996), 31 C.R.R. (2D) 92 at 96.

This was characterized in Stevens as either the dominant objective: ibid. at 247, 255-56, Scott C.J.M.; and/or the exclusive objective: ibid. at 286-87, 292-94, Twaddle J.A. of the current law. See the examples, supra note 101. In Gill and Lucas the defamatory statements related the conduct of prison guards and a police officer, so are conceptually similar to those involved in Hill. The character assassination undertaken in Stevens did not involve any element of the discussion of public issues.

Theophanus, supra note 90 at 18, Mason C.J., Toohey and Gaudron JJ.

Ibid. at 55, Deane J. 
western separatist party sued with respect to a description of the party as "an Alberta version of the Ku Klux Klan." ${ }^{106}$ A federal cabinet minister brought action regarding a story that he had visited a nightclub "featuring porn films, nude dancers and prostitutes" while on an official trip to Germany. ${ }^{107}$ Members of an Indian band council sued other band members who had publicly accused them of fraudulent mismanagement of band funds. ${ }^{108}$ Recently a police force and its members sued with respect to allegations of racist practices. ${ }^{109}$ These cases involve highly charged statements, with interwoven elements of fact and opinion, on highly charged issues. They are the work of "citizen-critics." 110 They may be emotional; they may not carefully distinguish fact and opinion; they may make mistakes with regard to evidence or inference; but they also make an obvious and essential contribution in a democratic society. That the common law of defamation has a real impact on vital political expression cannot be denied. Such an impact, which engages the central purposes of s. 2(b), should also engage the Charter in a meaningful way.

Under the current approach, the Charter is applied to criminal defamation law and not to civil defamation law. In one sense this may seem to have a legitimate connection to the purposes of free expression, as it may be thought that the stigma and penalties attached to criminal law make it peculiarly inappropriate for the regulation of expression." This ignores the significant deterrent effect of civil remedies, as discussed earlier. Further, it overlooks an important feature of criminal defamation law, that it provides protection for reputation in circumstances in which the civil remedy does not operate effectively. If the plaintiff cannot afford to sue or the defendant cannot afford to pay the costs of a suit, the civil remedy is meaningless. Thus it has been said "we must either have a criminal offence, or let the worst of the libelers go free."112 The criminal law protects the victim of defamation who is disadvantaged by his or her own lack of means or by the lack of means of the defamer. The effect of the current approach is that for common law plaintiffs, reputation outweighs the public interest in free expression, whereas for criminal law complainants, reputation must be balanced against the public interest. ${ }^{113}$ This result cannot be related to the goals of Charter

Christie v. Geiger (1986), 38 C.C.L.T. 280 (Alta. C.A.). The plaintiff was successful. The Charter was held not to apply because the publication occurred before it came into effect.

Coates v. The Citizen (1988), 44 C.C.L.T. 286 (N.S.S.C.). The Charter was held to apply because legislation had made some alterations to the common law; but no violation of $\mathrm{s}$. 2(b) was found. Derrickson v. Tomat (1992), 88 D.L.R. (4th) 401 (B.C.C.A.), (1992), 94 D.L.R. (4th) 453, leave to appeal to S.C.C. refused 93 D.L.R. (4th) vii. The plaintiffs succeeded at trial, but a new trial was ordered because of errors by the trial judge. Two of the three appellate judges commented that non-pecuniary damages should be limited in defamation actions by public officials. The decision was noticed but not commented upon by the Supreme Court of Canada in Hill, in which large general, aggravated and punitive damage awards were upheld: supra note 75.

Kenora (Town) Police Services Board v. Savino (1995), 36 C.P.C. (3d) 46 (Ont. Ct. (Gen. Div.)). The defendant's application to strike out the claim was dismissed.

The term is borrowed from Lewis, supra note 88 .

This argument was advanced, unsuccessfully, in R. v. Keegstra, [1990] 3 S.C.R. 697, with regard to the regulation of hate propaganda.

Stevens, supra note 100 at 298, citing J.R. Spencer, [1983] Crim. L.R. 524 at 527-28.

This is another example of the inequity that results when the Charter is used as a brake on redistributive efforts of government, and is not applied at all to governmental enforcement of common law entitlements. See e.g. supra note 28 and accompanying text. 
generally, or of the guarantee of free expression in particular. The costs and benefits of open debate should be more equitably distributed.

\section{CONCLUSION}

The common law of defamation, despite its first encounter before the Supreme Court of Canada with the Canadian Charter of Rights and Freedoms, and despite its oftrecognized potential to penalize and deter important political expression, remains today "essentially the product of its historical development up to the seventeeth century." 114 I have argued that the courts' creation and enforcement of the common law of defamation is governmental action that should be reassessed in light of the value that we place upon free and open criticism of governmental institutions and the persons who operate them. Because the Supreme Court of Canada has held that the Charter does not apply to the common law in private litigation, and has minimized the impact of the Charter when the judiciary develops the common law in accordance Charter values, this reassessment has not occurred. The governmental action doctrine in its current state does not achieve the purposes of restricting Charter application to private action. The approach to the development of common law to accord with Charter values, as compared with Charter application, does not reflect real differences in the kinds of litigation in which the different analyses will be used. There are far too many arbitrary restrictions on the impact of s. 2(b) of the Charter that deny it the meaning that it should have with respect to expression central to its purposes. It is time for the common law of defamation to enter the age of the Charter. 